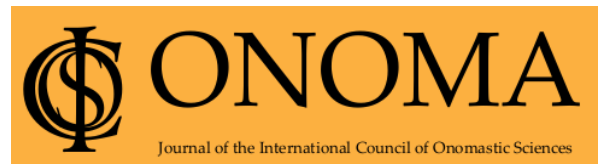

Onoma 56

Journal of the International Council of Onomastic Sciences

ISSN: 0078-463X; e-ISSN: 1783-1644

Journal homepage: https://onomajournal.org/

\title{
Tendencies in the development of contemporary official anthroponymy in Czechia and Slovakia
}

\section{Milan Harvalík*, Iveta Valentová}

Ludovít Štúr Institute of Linguistics, Slovak Academy of Sciences

To cite this article: Harvalík, Milan \& Valentová, Iveta. 2021. Tendencies in the development of contemporary official anthroponymy in Czechia and Slovakia. Onoma 56, 37-55. DOI: 10.34158/ONOMA.56/2021/3

To link to this article: https://doi.org/10.34158/ONOMA.56/2021/3

(C) Onoma and the authors.

\section{Article history}

Received on 25 July 2021.

Final form accepted on 2 December 2021.

Published online on 13 December 2021.

Tendencies in the development of contemporary official anthroponymy in Czechia and Slovakia

Abstract: The system of proper names in Czechia and Slovakia has undergone certain significant changes, especially after the change of political regime in 1989 and after the division of the common state, Czechoslovakia, in 1992. The core of the study deals with the changes, characteristic features and tendencies in the development of official anthroponymy in both countries from 1989 up to the present. The sociopolitical changes have also led to certain changes in the laws on first names and surnames and in their entries in the Registrar's Offices and, above all, to more intensive internationalization of the naming systems of both countries.

Keywords: Proper names, official anthroponyms, first names, surnames, Czechia, Slovakia.

* Contact: L’udovít Štúr Institute of Linguistics, Slovak Academy of Sciences, Panská 26, 81101 Bratislava, Slovakia,milan.harvalik@juls.savba.sk 


\section{Les tendances du développement de l'anthroponymie officielle contemporaine en Tchéquie et en Slovaquie}

Résumé : Le système des noms propres en Tchéquie et en Slovaquie a enregistré certains changements importants, en particulier après le changement du régime politique en 1989 et après la dissolution de l'État commun, la Tchécoslovaquie, en 1992. Le cœur de l'étude porte sur les changements, les caractéristiques et les tendances du développement de l'anthroponymie officielle dans les deux pays de 1989 à nos jours. Les changements sociopolitiques ont également provoqué certains changements dans les lois sur les prénoms et noms de famille ainsi que dans leurs inscriptions dans les registres et, surtout, une plus grande internationalisation des systèmes de dénomination des deux pays.

Mots-clés : Noms propres, anthroponymes officiels, prénoms, noms de famille, Tchéquie, Slovaquie.

\section{Tendenzen in der Entwicklung der gegenwärtigen offiziellen Anthroponymie in Tschechien und in der Slowakei}

Zusammenfassung: Das System der Eigennamen in Tschechien und in der Slowakei hat einige bedeutende Änderungen erfahren, insbesondere nach dem Wechsel des politischen Regimes im Jahr 1989 und nach der Teilung des gemeinsamen Staates, der Tschechoslowakei, im Jahr 1992. Der Kern der Studie befasst sich mit Veränderungen, charakteristischen Merkmalen und Tendenzen in der Entwicklung besonders der offiziellen Anthroponymie in beiden Ländern von 1989 bis heute. Gesellschaftlich-politische Veränderungen haben auch $\mathrm{zu}$ einigen Änderungen der Gesetze über Vor- und Familiennamen sowie zu deren Eintragung in die Personenstandsregister und vor allem zu einer stärkeren Internationalisierung der Benennungssysteme beider Länder geführt.

Schlüsselbegriffe: Eigennamen, amtliche Anthroponyme, Vornamen, Familiennamen, Tschechien, Slowakei. 


\title{
Tendencies in the development of contemporary official anthroponymy in Czechia and Slovakia ${ }^{1}$
}

\author{
Milan HaRVALÍK AND IVETA VALENTOVÁ
}

\section{Introduction}

In addition to linguistic factors, also extralinguistic, especially social, influences have always played a significant role in the formation and development of the particular proper names and onymic systems of all languages. This fact is understandable, as proper names constitute not only a linguistic, but also a broad social phenomenon, and so they reflect the development of the society as well as changes occurring within it (see Harvalík 2013). The same applies to contemporary Czech and Slovak, too. The set of proper names that exist and are used in these languages has undergone significant changes in recent years. However, upon detailed examination it is clear that their intensity and dynamics do not manifest themselves in the same way in the particular groups and subgroups of proper names. In this article we deal with changes and tendencies in the development of official Czech and Slovak anthroponymy, i.e. of Czech and Slovak official anthroponymic systems in the period from the year 1989 to the present. The main topic of the article is preceded by a brief characterization of the anthroponymic systems of $\mathrm{Czech}^{2}$ and of Slovak ${ }^{3}$.

Czech and Slovak form the Czecho-Slovak subgroup of West Slavic languages, which also include Polish, Kashubian and Upper and Lower Lusatian Serbian. Hence, Czech and Slovak are close to each other and mutually comprehensible; the differences between them are smaller than the differences between some dialects of other languages. The dialects of Czech and Slovak form a linguistic continuum, i.e. the transition between them is smooth.

The proximity of both languages and their mutual relations are also reflected in the anthroponymic systems of Czech and Slovak, which during the existence of the common state underwent similar development, as they were influenced by similar political, economic, cultural, social and other extralinguistic factors. The usage of official personal names (i.e. first names and surnames) in Czech and in Slovak was at that time conditioned by the same laws that were uniform and binding for the whole of Czechoslovakia. However, it is necessary

\footnotetext{
This study was supported by grants VEGA No. 2/0019/20 and No. 2/0133/20.

For more details see Pleskalová (2007), Harvalík (2012).

For more details see Giger \& Giger (2007).
} 
to emphasize the significant similarity marking both these systems as to their development and developmental tendencies, but not the similarity of the particular repertoires of Czech and Slovak first names and surnames, which considerably differ from each other as a result of the development of Czech and Slovak within different political units before the establishment of Czechoslovakia, as the anthroponymy of both these languages was formed over a number of centuries, and its core remained relatively stable even during the existence of the common state.

The dissolution of the Czechoslovak Federation on 31 December 1992 and the establishment of two new independent states, the Czech Republic and the Slovak Republic, on 1 January 1993, brought greater or lesser differences in the political, economic, social and cultural development of Czechia and of Slovakia. These differences were also reflected in Czech and Slovak, and subsequently also in their anthroponymic systems. The time gap of almost thirty years since the division of Czechoslovakia allows for a confrontation of their development within this period.

In the Czech Republic and the Slovak Republic, there is a two-element official naming system that consists of a first name and a hereditary surname. It was officially codified in the 1780s by Emperor Joseph II, making the surname obligatory and obligatorily hereditary (Knappová 2008: 9; Pleskalová 2011: 94). At the time when a decree on obligatory and permanent surnames was issued in the Austrian monarchy, a two-element naming system with a hereditary surname had been operating within the territory of today's Czechia and Slovakia for at least several decades, but often at least for two centuries. In essence, the pre-existing state became legalized. In the official two-element naming system, the first name was reassessed to the determining member, and the surname became the basic member.

\section{First names}

The most striking changes occurred mainly in the system of first names (both in their basic and their hypocoristic forms). As in many other countries, in the Czech Republic and the Slovak Republic the rules for selecting the names and their entry in the Registry are laid down by law (in the Czech Republic it is the Act on Registries, Names and Surnames No. 301/2000 of the Corpus Iuris, in the Slovak Republic the Act on Name and Surname No. 300/1993 of the Corpus Iuris, the Act on Registries No. 154/1994 of the Corpus Iuris, or the Act on the State Language of the Slovak Republic No. 270/1995 of the Corpus Iuris ${ }^{4}$ ). Pursuant to the above laws, only the basic, standard forms

4 The implementation of legal rules to the Act on Registries specified in Decree No. 302/1994 of the Corpus Iuris, which includes the provisions on the name of the person and its entry in the Registry, are only general, as the merit of the decree is the implementation provision to the paragraph wording of the Act on Registries and their management. 
of orthographically documented first names can be entered in the Registry Records (hence, the first names cannot be distorted, diminutivized, or entered in their hypocoristic forms). It follows from the above that in Czechia it is possible to spell the names in their Czech form and in Slovakia in their Slovak form, as well as - in both countries - in the foreign spelling forms of borrowed first names, e.g. Czech Jiř́, Slovak Juraj, but also the German Georg, English George, Russian Jurij or Italian Giorgio. However, it is not possible to register a name whose spelling or grammatical variant does not exist in any foreign language system. The parents cannot determine the orthographical form of the name. For example, in Czechia, the registration of the name Milada as Mylada was not approved, and the non-existent forms Jullian, Ammálie or Zdennka have not been recommended either (Knappová 2017: 52).

It is not possible to register generic nouns or other kinds of proper names as first names. Thus, surnames may not be entered in the function of first names, although traditionally in Czechia and in Slovakia, a whole relatively large group of surnames has developed from first names. Neither may the name of an inhabited or uninhabited area, company, product, etc., be entered as a first name. A female first name cannot be registered for a male person and vice versa, as the first name must be in accordance with the gender of the person named.

Of course, it is not possible to check all the employees of the Registries, and therefore it may happen that, for example, even a non-existent spelling of a name is registered. In this respect the laws are vaguer in Slovakia than in Czechia. Due to increased migration after 1989, such names are registered for children returning or coming from countries as e.g. USA, where the registration of first names is not officially regulated, and it is possible to register any name for a child. In these cases, the name must be entered in the identity documents according to the name on the birth certificate issued in such a country for the particular child.

A significant change compared to the previous wording of the law in Czechia is the fact that at present two first names can also be entered into the Register for a citizen of the Czech Republic (the addition of the second first name can be requested). In Slovakia, laws allow entering up to three first names. Due to the growing number of immigrants from countries where the naming system includes the so-called otchestvo, patronymikon, or patronym ${ }^{5}$ (i.e. the name after the father of the child, e.g. Ivanovič, spelled Ivanovich in English, used in the name of the person as Ivan Ivanovic Petrov), the number of requests for such official registrations is increasing. Since in Czechia and Slovakia there is a two-element, not a three-element naming system, Czech and Slovak laws do not allow their citizens to record otchestvo in the registers. In Czechia, in such cases it is possible to register the father's name as the

5 In Russian отчество, in Ukrainian по батькові, in Belorussian імя по баиьку (Svoboda et al. 1983: 269), in Bulgarian бащино име (Balkanski \& Cankov 2016: 48). 
second first name (though not in the form of a patronym, i.e. with the suffix -ovic, -evič or -ič - in English the corresponding spelling is -evich, -ovich or -ich, respectively-, e.g. Petrovič, Vasiljevič, Iljič, but in the basic form of the father's name, e.g. Petr, Vasil, Ilja) (cf. Knappová 2017: 64-65), while in Slovakia it is registered in the form of a patronym as one (the first) of the surnames ${ }^{6}$.

Especially in mixed marriages, in which one of the parents (usually the father) comes from a country where the so-called middle name is used, parents sometimes ask for the middle name of their children to be entered into official documents. However, due to the two-element naming system and the applicable laws (see above), it is possible to satisfy these requests in Czechia only if the form of the middle name is identical with some basic, standard form of a first name whose spelling has already been documented, so that from the point of view of the Czech laws it can be considered the second first name (e.g. David Michael Newman). In Slovakia, a name conflict often arises for children who have dual citizenship of the Slovak Republic and another state (e.g. a child born in the USA, Great Britain, etc.). In many cases, the child's middle name is the last name of one of the parents. If in these cases the parents insist on the registration of the child's middle name in Slovakia, the Registry rejects such requests, or the surname of the child's parent functioning as the child's middle name is entered as one (the first) of the surnames.

When registering the name, the Registries in the Czech Republic have at their disposal Knappová's publication Jak se bude vaše dítě jmenovat? ('What will your child's name be?', 2017), and in Slovakia the handbook by Majtán \& Považaj, Vyberte si meno pre svoje diet'a ('Choose a name for your child', 1998), which contain lists of official forms of names. Nevertheless, it is also possible to enter first names that are not mentioned in these publications if they meet the relevant legal conditions. It would be appropriate to update the publication of Majtán \& Považaj in view of the more than 20-year period that has elapsed since its publication. The Ministry of the Interior of the Slovak Republic has prepared several guidelines for entering a first name into the Registries. However, the list of these guidelines is not publicly available.

When registering a foreign first name in Slovakia, the parents are obliged to provide cooperation with the Registry Office in the case of a name whose form and use is not generally known and documentable for its being entered in the Registry. Parents usually turn to L. Štúr Linguistic Institute of the Slovak Academy of Sciences or to embassies and submit a request for their opinion with regard to such first names. Unlike the situation in Slovakia, it follows from Article 62 of the Czech Registry Act that in case of any doubts about the

6 In Slovakia, the name of a child who is a citizen of the Slovak Republic and also acquires citizenship after his or her father-foreigner, is in general registered in accordance with the Slovak naming system. However, if the parent documents that the child is a citizen of another country in which patronyms are a part of the system of names, and the parent requests the registration of the patronym, the patronym is registered as one of the surnames. 
correct spelling, the citizen is obliged to submit an expert opinion that can only be issued by an individual or an institution qualified to conduct expert work. ${ }^{7}$ The expert verifies the basic, written form in the particular language and in its spelling system, using special dictionaries of foreign personal names, which are professionally credible, or consults the form of the requested name with an expert in the particular language. In justified cases (in the absence of the necessary professional literature or when it is impossible to verify the correct form of the name with an expert), the statement of an authority from the country where the name is supposed to come from (embassy, Ministry of Culture, Education, etc.) can also serve as a basis for issuing an expert opinion. The various names of anonymous nature listed on the Internet are not considered to be officially recognized linguistic sources in Czechia or Slovakia, and therefore they are not used as the basis for expert verification of the spelling of a name. However, sometimes they can be useful as auxiliary material. The linguistic expert opinions in Czechia, or the statements of Slovak linguists, or of the embassy staffs in Slovakia serve the Registries, and they are certainly helpful for them, but in the end, only Registries have the authority to decide on the registration of a name in both countries.

As in previous times, the selection of first names for the newborn is to a varying extent influenced by family and local customs, linguistic influences, social status and education of the parents, their interests, profession and friends, religious influences, contemporary popularity of names, popularity of famous personalities, and an effort to revive unused first names (for more details cf. above all Knappová 2017: 26-40, Majtán \& Považaj 1998: 21-27). However, a characteristic feature of the changes in the inventory of the first names used is the higher speed of internationalization, which is the result of more intensive contacts between our countries and the world, the possibility of Czech and Slovak citizens to travel abroad and of foreigners to visit the Czech and Slovak Republics, as well as a larger number of ethnically mixed marriages (cf. Knappová 2017: 22-23; Harvalík 2018: 284-285; Valentová 2017: 168). In contrast to the previous period, as a result of these influences, Registries are under much stronger pressure when entering children's names. The names of various media heroes and characters from films and books, mainly those produced abroad, which before 1989 were not extensively available in the two countries, also have a considerable influence on the fashionability of first names. The name of a child is determined by the agreement of the parents; it is an expression of their will. The role of Registries is to guide them in this

7 For example, in addition to Miloslava Knappová, the Department of Onomastics of the Czech Language Institute of the Academy of Sciences of the Czech Republic, v. v. i., in Prague is authorised to issue expert opinions in the fields of education and culture pertaining to linguistic expertise - namely, verification of forms of first names and surnames in relation to legal provisions governing how names must be entered in personal identification documents. 
decision-making and to advise them that the choice of name should be in accordance with the tradition, it should suit the surname, but the Registries should not prohibit a name, unless the choice of name is contrary to the law, good morals and the like. Both countries are trying to regulate this issue very sensitively, taking into consideration the requirement that there is no violation of the rights and freedoms of the citizens with regard to the particular constitutions and international conventions. The name belongs to its holder and its choice or change is a manifestation of his or her personal freedom. Therefore, although certain limits must be set, there is relatively much room left for a sufficient degree of freedom. ${ }^{8}$

A novelty compared to the previous period is the selection of the so-called gender-neutral name (in Slovak also obojrodové meno, in Czech obourodé jméno, oboupohlavní jméno 'unisex name') for people who undergo gender change, names such as Alex, Kim, Nicol, Saša, which are mostly of foreign origin. Because of the cases of temporary assignment of names to persons undergoing gender reassignment, amendments to existing laws have been made in both countries. Czech Act No. 301/2000 of the Corpus Iuris and Slovak Act No. 300/1993 allow citizens to request the Registry Office (in Slovakia, the District Court) to change their name and surname to a gender-neutral name, on the basis of a confirmation from the medical facility that they have started the gender reassignment treatment. In Slovakia, however, no criteria have yet been formulated to determine which names can be considered gender neutral. In Czechia, some criteria for the list of neutral first names for Registries have been determined by Knappová (2017: 88-94). Given the fact that according to law, a name should also express the sex of its bearer, in the case of the permanent entry of the neutral form of a name in the Registry, Knappová (2017: 89) recommended the registration of another first name which clearly determines the gender of the bearer, e.g. Christie Daniel, Christie Sofia.

An important stimulus for the development of the system of Czech and Slovak first names (i.e. first names used in the Czech and Slovak languages, regardless of whether their origin is domestic or foreign) is constituted by the expansion of the repertoire of names used. Four ways of doing this have been identified, namely reconsidering, "officialising" the hypocoristic forms of names that have lost their emotional colouring, reviving obsolete names and names used in the past, creating hitherto non-existent or unused feminine forms of masculine names, and borrowing names from foreign languages (Knappová 2017: 44-45).

When selecting and entering first names in the Registries in Czechia and Slovakia, in addition to the already mentioned tendencies, some specific trends were also manifested:

8 For more details on the manner of entering names into Slovak Registries and their codification see Valentová (2017). 
a) In previous periods, when borrowing foreign first names, their written form to a larger extent underwent adaptation to the domestic graphical system, and their ending was adapted to the morphological needs of Czech and Slovak (cf. e.g. the Czech and Slovak form Žaneta instead of the French Jeannette). At present, in contrast to the previous situation, the registration of names in their original foreign language form is more frequently requested. However, applications for registering a modified Czech or Slovak form of foreign first names are also documented, but in many cases this is rather due to the applicants' ignorance of the correct written form of the name, and it is their attempt to record the sound form of the name by a graphical system existing in the target language, i.e. in Czech or in Slovak. Some other language variants of names are becoming more popular than their Czech or Slovak official forms. For example, in Czech the female name Sofia is favoured more than its Czech form Žofie. Similarly, Agáta is preferred to the Czech form Háta, the male name Sebastian is more frequent than its Czech form Šebestián, and the male name Denis is about 180 times more frequent than its Czech form Diviš. In Slovak Registries ${ }^{9}$ the French, English or German orthographic form Nicolas is more frequent than the official Slovak form Mikuláš; parents in Slovakia more often ask that a Latin, German, Danish, Swedish, Spanish and English form of the name Tobias is entered into the Registry as the name of their children rather than the Slovak official form Tobiás. Among the female names, more popular than their Slovak official forms Ema, Ela, Nela are the spelling variants with double consonants, e.g. Emma, Ella, Nella.

b) In Czech and Slovak the official feminine forms of names are formed from masculine forms with the help of a feminizing suffix, i.e. in particular by adding - a, e.g. Daniel - Daniela, Ivan - Ivana, Stanislav - Stanislava. Such forms of female names are based on the system of Czech and Slovak as inflected languages, as well as on the development and tradition of the formation of domestic female names and their functioning in the official and unofficial naming spheres. Another group consists of female names that originally had the ending $-a$, i.e. were proprialized from appellatives which already had such an ending. Also the Czech, but above all the Slovak, official domestic forms of borrowed female names ending in a consonant are formed by adding the ending $-a$, e.g. Dagmar $>$ Dagmara, Miriam $>$ Miriama, or Ester $>$ Estera. However, especially in Slovakia, it has become fashionable to enter into the Registers and use these foreign feminine forms of names without the added ending $-a$. A diachronic comparison of the frequency of this type of first names between Czechia and Slovakia shows that the tendency to write them without a final $-a$ is stronger and more stable in Czechia (it is documented without any significant fluctuations throughout the 20th century) than in Slovakia. Hence, in Czech it is not a

9 We base our statements on the frequency of the first names in Registries within the years 2006-2015. 
current fashionable trend, but a rather constant phenomenon. ${ }^{10}$

c) Already in the past, there was a tendency to shorten long vowels in some official Slovak forms of first names. This concerned in particular the shortening of the vowels $o$ and $e$, which are peripheral in the Slovak phonological system, and of the vowel $i$ in the names Róbert, Adónis, Margaréta, Gréta, Magdaléna, Xavér, Filoména, Ervín, Albín, Renáta, Regína, and Títus. This fact has already been pointed out by Pisárčiková (1989: 149). This trend continues, e.g. more frequent are the forms Artur, Juliana, Oskar, Sebastian, Timea than the official Slovak forms Artúr, Julián, Oskár, Sebastián, Tímea. In some names, such as Artúr, Oskár, the decision to spell the Slovak official forms with a long vowel was influenced by Hungarian (cf. Hungarian Artúr, Oszkár), but in general, in Slavic as well as non-Slavic languages and, of course, in Slovak too, these names are also used with a short vowel (cf. e.g. Czech, Serbian, Croatian, Polish, Russian Artur; Czech, Polish, Ukrainian Oskar; see also Ladó \& Bíró 2004, Knappová 2017).

Compared to the situation before 1989, the use of first names (in basic, but also in their hypocoristic forms), began to appear more markedly in Czechia and Slovakia in formal address and often together with pane, pani, slečno (Czech), pán, pani, slečna (Slovak) (Mr., Mrs., Miss respectively) also in such communication situations in which it had not been customary earlier (television competitions, phone-ins by radio listeners, etc.). The reasons for the spread of this phenomenon can be seen in adopting the conventions used in some foreign languages, in a lower degree of formality, and in an effort to create an atmosphere of close contact, friendship and intimacy, while - on the other hand - to maintain also a certain anonymity by using only the first name. If the participant in a competition is addressed only by his/her first name or if the caller does not introduce himself of herself by their last name, it makes it difficult to identify him or her, which may be convenient in certain circumstances (Harvalík 2010: 180).

\section{Surnames}

In connection with the above-mentioned internationalization, among the surnames used in Czech and Slovak, recently we also encounter an everincreasing share of surnames of foreign origin, whether they be surnames of foreigners who come to work and live in the Czech Republic and the Slovak Republic, or surnames of personalities from the spheres of political, social and

10 In Slovakia, the increased fashionability of registering these names is also related to the fact that before the Act on First Names and Surnames No. 300/1993 of the Corpus Iuris came into effect, perhaps more preferred in entering the names into Registries (Birth Registries) were the official forms of first names that respect the pronunciation, spelling and grammatical principles applying in Standard Slovak, i.e. - with some exceptions - the forms ending in - $a$ (for more see Valentová 2017: 167, 174). 
cultural life about whom the mass media provide information. It can be stated that both in Czech and in Slovak as inflected languages, at present the inclusion of foreign surnames in one of the declension paradigms according to their ending is almost obligatory. Only those surnames which, due to their final sounds, cannot be assigned to any of the declension types, behave as non-declinable. ${ }^{11}$

For some users of the two languages, feminizing or not feminizing women's surnames has become a sensitive and topical issue. In Czech and in Slovak, each male surname has its female counterpart, which is formed from the male form by feminizing it. Such formation of special feminine forms of surnames is characteristic of some Slavic and non-Slavic languages. In Standard Czech and Slovak, official forms of women's surnames are created from nominal masculine surnames by means of the feminizing suffix -ová (Novák > Nováková, Kováč > Kováčová). Adjectival forms of female surnames, which were formed from qualitative and relational adjectives, are formed in the same way as the forms of these adjectives (Plachý > Plachá, Jesenský > Jesenská). The grammatical gender of surnames in both languages is derived from the natural gender, and so surnames fulfil two basic functions: identification of the person and identification of the gender (cf. e.g. Ološtiak 2001: 299).

The origin of feminizing the surnames of women in both countries can be traced back to the 13th century when the situation in naming persons began to change significantly. Gradually, a two-element naming system began to be formed. The name of the father or another relative, the designation of family relatedness or social classification, employment, ethnicity or gender, the place of residence of the family, etc. were added to the person's name. Such more precise identification of persons was required by the social need in a developing feudal society, especially in connection with administrative and legal acts. Although within the formation of the secondary naming system feminine surnames with the feminizing suffix -ova were initially perceived as specific denotations expressing relatedness, they did not express ownership, but kinship to the father (patronymic relationship) or to the husband (maritonymic relationship). The possessive meaning of this suffix, which is present in the appellative lexicon, is not perceived in women's surnames, as this form has been lexicalized, as also emphasized by the vowel length in the suffix -ová. Diachronic research of the naming systems of personal names has shown that feminization of surnames, as well as their declension, has been a characteristic feature of the Czech and Slovak linguistic systems, and in both of them it was developing since ancient times (Knappová 2008: 36; Pleskalová 2011: 72-73, 122-126; Valentová 2013, 2016, there also references to other literature).

In the Czech Republic the basic legal regulation for the form of registration of women's surnames into official documents is Act No. 301/2000 of the Corpus Iuris on Registries, Names and Surnames, in the wording of its amendment No. 312/2013 of the Corpus Iuris. In Article 69 it stipulates that

11 For more see Knappová (2008), Blanár (2005: 32-37), Majtán (2014: 10). 
the surnames of women are formed in accordance with the rules of Czech grammar, i.e. in the feminized form. When registering the marriage, it is possible, at the request of the woman concerned and in view of the surname she will use after getting married, to enter in the Register the masculine form of the surname in the case of a) a foreigner, b) a citizen who has or will have a permanent residence abroad, c) a citizen whose husband is a foreigner, d) a citizen who is of a nationality other than Czech. Similar rules also apply for registering the birth of a female child. At the request of the parents, it is possible to enter the child's surname in the masculine form if the child is a) a foreigner, $b$ ) a citizen who has or will have a permanent residence abroad, c) a citizen one of whose parents is a foreigner, d) a citizen who is of different nationality than Czech (cf. Knappová 2008: 36-37). Slovak laws also give women the opportunity to register their surname in the masculine form in cases where such solution could be really functional. Such change is intended to ensure that the surname has a form that is in accordance with the law or tradition of another state (Act on Name and Surname No. 300/1993, Article 6, sub. 5). According to Act on Registries No. 154/1994, Article 16, the entry of a female surname without the Slovak feminizing suffix for a person who is not of Slovak nationality shall be permitted: a) if the parents so request when entering the surname of their female child in the Registry of Births, or if adoptive parents so request at the registration of the last name of their adopted child, b) if so requested by the bride when the marriage is entered into the Registry of Marriages, c) if so requested by the woman in connection with entering the decree on surname change pursuant to a special law.

In recent years, especially in the mass media, there has been a tendency not to feminize particularly the surnames of foreign female personalities, such as famous artists, sportswomen or politicians. According to tradition, the surnames of some famous personalities (e.g. Edith Piaf, Marilyn Monroe, Gina Lollobrigida) are usually not feminized in Czech. The rules of Slovak orthography (Pravidlá slovenského pravopisu 2013: 130) admit that the foreign surnames of well-known artists (especially in a context requiring the nominative case in the sentence) may be left in a non-feminized form. Both in Czech and Slovak, the surnames of some foreign female writers on book covers also remain non-feminized, as their names are perceived as trademarks. As a rule, some types of domestic surnames are not feminized, either, e.g. in Czech names in the form of the genitive plural of the Jani type, which is identical for both sexes. In Slovak, for example, the surnames which originally were family possessive adjectives in pluralia tantum do not have to be feminized (Balažoviech, Miškech, Maleckých, Jakubovie). In ordinary Czech and Slovak communication, the usage of feminizing women's foreign surnames is inconsistent, depending on the type of discourse, social, generational and other classification of speakers and other factors. However, feminization is a natural feature of Czech and Slovak, and this is also the way it is qualified in grammar and language manuals. Each language has the sovereign right to adapt not only foreign appellatives, but also proper names 
according to its own laws, cf. e.g. the Latvian forms of Czech names Jindržihs Šimons Bārs (Czech Jindřich Šimon Baar), Ivan Blatnijs (Ivan Blatný), Jiržìjs Stanislavs Gut-Jarkovskis (Jiři Stanislav Guth-Jarkovský) or Milan Harvalīks (Milan Harvalik). Therefore, feminization of foreign female surnames can be recommended as only a more cultivated form of expression. However, it is always necessary to distinguish between feminizing the surnames in ordinary communication, where it is appropriate, and in official documents of legal nature, in bibliographic records, etc., where the original, non-feminized forms of surnames should be respected (Harvalík 2016). ${ }^{12}$

Although we do not have at our disposal any relevant statistics, it can be stated that at present Czech and Slovak women more often have the masculine form of their surname registered than was the case before 1989, hence not only if they are of another nationality or if they marry a person of another nationality or a foreign citizen. If after having married a Czech citizen, a woman of Czech nationality and having Czech citizenship wants to use the non-feminized form of her married surname, she will either make a declaration on the basis of the above-mentioned Czech law that she is of a nationality other than Czech, or that she has or will have permanent residence abroad. In Slovakia the first entry of the surname of a woman who just got married is made in the feminized form, but according to Article 19 of Act on Registries No. 154/1994, she may subsequently request the issuance of an official transcript stating her surname without the suffix -ová. However, in Slovakia, in contrast to the situation in Czechia, such request does not have to be supported by entitlement. Nevertheless, some women of Slovak nationality prefer to state a different nationality in the application for marriage, in order to make sure that their surname is registered in its male form already at its first registration and that the feminized surname form is registered neither in the records of the registry, nor in their marriage certificate (cf. also Vinczeová 2016: 96).

In public, official, or even in ordinary, unofficial communication, a woman's non-feminized surname seems just as unnatural as if one would refer to the woman in the masculine gender, not to mention the problems with its declension. From the point of view of the social status of the bearer of the surname, the non-feminized surname may rather appear as an attempt to hide the female identity, but this is probably only a temporary trend taken over from foreign naming conventions and linguistic systems. The right of any woman to

12 When choosing a feminized or non-feminized form of a foreign female surname, the parallel offered is that between exonyms and endonyms. Language users must have a functional approach to using them. The speaker should use either the original or the domestic version of the name, depending on the situation. If the emphasis is on accuracy and unambiguous orientation, it is appropriate to use an endonym, but in ordinary conversation it is more appropriate and natural to use an exonym. Such functional differentiation and situational conditionality enrich the expressive possibilities of language and can be useful for its further development (cf. Harvalík 2004: 123). 
decide whether the official form of her surname will be in the feminine or nonfeminine form is completely legitimate, but just like feminization of surnames in ordinary communication is not governed by law, decree or regulation, neither can in ordinary communication any absence of feminization be ordered. Thus, a woman with a non-feminized surname can commonly expect that her surname will be feminized/non-feminized and that it will sometimes be treated as if it were masculine (non-existent and grammatically incorrect in Czech *s paní Novákem, or in Slovak *s pani Novákom, both supposed to mean 'with Mrs. Novák'). It may happen that the non-feminized surname will be declined according to the corresponding female appellative paradigms (Czech s pani Kozou, Cibulkou, Slovak s pani Kozou, Cibul'kou), which may seem unnatural or even ridiculous, because in such cases surnames that are homonymous with appellatives (Czech and Slovak koza 'goat', Czech cibulka, Slovak cibul'ka, both 'little onion') can (though do not have to) be as if retroactively appellativized, when connotations connected with the motivating appellatives are added to them. Feminization of non-feminized female surnames (domestic as well as foreign) in ordinary communication may be perceived by their bearers as an inappropriate modification, but any insistence on using surnames of women in male forms forcibly interferes with the Czech and Slovak linguistic systems, and those who are adherents to feminization may have the feeling that they are being forced into expressions that are foreign to them and are considered by them as being uncultured.

Another observable tendency in both languages is the registration of two surnames for women after their getting married. In the case of entering two surnames, the surname of the husband comes on the first place and the maiden surname of the wife on the second place. Especially media-famous women tend to adopt the surname of their husband in its non-feminized form (in Czechia, for example, this is the case of the politician Lenka Teska Arnoštová, the director and screenwriter Karin Krajčo Babinská, the model and presenter Petra Eliáš Voláková, the presenter Tereza Šnajdr Stýblová, and in Slovakia of the singer Sisa Lelkes Sklovská, the TV anchor Miriam Šmahel Kalisová, the tennis player Dominika Navara Cibulková, etc.), although the husband does not always have to be of a different nationality or citizenship than Czech or Slovak. If the husband is not a foreigner or a member of another nationality, the reason for registering a male form of a surname is usually only a matter of a fashionable trend. Even according to the findings of Garančovská \& Kopásková (2009: 164), the reasons are mostly petty: "it is fashionable and it sounds better". According to Vinczeová (1996: 96), from the legal point of view, however, both surnames should have the same form, i.e. be either feminized or non-feminized, and a form of surname in which the first part is not feminized and the second one is feminized should not be used.

On the other hand, in lively, colloquial usage of domestic surnames, feminization is clearly preferred. Female surnames are also feminized by means of other suffixes than those listed. Actually, in contrast to the situation in Standard 
Czech and Slovak, the repertoire of dialectal derivation suffixes is wider (Harvalík 2006). However, Czech research proves that literary and dialectal forms function side by side in dialects, depending on the official character of the communication situation (cf. Hlubinková 1996: 56; Kolařík 1999: 63) and/or on the generational affiliation of the communicators (Kolařík 1999: 63).

The results of recent research into the functioning of a living, non-official system of personal names in various Slovak localities also show that in common communication for denoting women, domestic surnames are not used in their non-feminized form and, moreover, are feminized not only by means of their official feminizing suffix, but also by means of dialectal suffixes (cf. also Valentová 2016: 16-17). With regard to domestic surnames, feminization, whether by using the suffix -ová or some other Common Czech and regional suffixes, is also a basic, common and living phenomenon in ordinary Czech communication.

The opinions opposing feminization, including e.g. the stressing of the socio-ethical postulate according to which each person has the right to his or her name being respected by preserving the original orthography of the name, or by having the authenticity of the name respected as a manifestation of civilization, etc., have been concisely denoted by Ološtiak (2001: 299) as extralinguistically motivated. He believes that these opinions have a rational core, which, however, is determined by the non-professionalism of their authors (mostly non-linguists) who have the tendency to overestimate the extralingual aspect of onymy.

\section{Conclusion}

Although the two-element anthroponymic system (first name and surname) is codified in Czechia and Slovakia, this does not mean that it is not subject to change even if the two-element system is maintained. Social and political changes can cause some changes in the official naming system, too. In the case of the Czech Republic and the Slovak Republic, such changes occurred after the change of political systems after 1989 and after the division of Czechoslovakia in 1992. The opening of the borders caused increased travel opportunities, intensified contacts between the two countries and the rest of the world, and led to a higher influx of foreigners. One of the consequences was the increased number of ethnically mixed marriages and, as a result, of a growing number of foreign personal names. The choice of first names was mainly influenced by the better availability of foreign books, films and TV series, and by the increased popularity of their main characters. The development of computer technologies and the Internet also played a significant role in the changes of the official and non-official anthroponymic systems. It can be stated that the period after 1989 is characterized by more intensive internationalization compared to the previous period. Changes in the laws allow for two first names to be entered in the Registry in the Czech Republic and for up to three first 
names in the Slovak Republic. Citizens of both countries are more likely to have their children's names registered in the Registries in their foreign spelling variants, which in some cases have become more frequent than their domestic forms (e.g. Sofia instead of Žofia in Czechia, Nicolas instead of Mikuláš in Slovakia). The inventory of official forms of first names has been expanded to include new first names. A novelty compared to the previous period is the choice of the so-called gender-neutral names for people undergoing gender reassignment. In the area of surnames, the issue of non-feminizing women's surnames has become topical. Despite the fact that, due to various reasons, especially after getting married, more and more women have had the masculine form of their surname entered in the Registry, according to the results of research on nonofficial anthroponymy, in ordinary communication domestic surnames of women are used in their feminized form. Although the usage of feminized/non-feminized foreign female surnames is not unified, for both languages feminization is a natural phenomenon in terms of their linguistic system, the development of their anthroponymic naming system, and their cultural traditions.

\section{References}

Balkanski, Todor \& Cankov, Kiril. 2016. Enciklopediya na bălgarskata onomastika [Encyclopaedia of Bulgarian onomastics]. Veliko Tărnovo: Universitetsko izdatelstvo Sv. sv. Kiril i Metodij.

Blanár, Vincent. 2005. Morfologické kategórie vlastných mien [Morphological categories of proper names]. In Kačala, Ján (ed.), Jazykové kategórie $v$ teórii a praxi [Language categories in theory and practice], 21-52 (with a summary in German on p. 51). Bratislava: Univerzita Komenského.

Garančovská, Lenka \& Kopásková, Ivana. 2009. Po svadbe s dvomi priezviskami [With two surnames after the wedding]. In Ološtiak, Martin \& Ivanová, Martina \& Gianitsová-Ološtiaková, Lucia (eds.), Varia XVIII. [Varia XVIII], 161-167. Prešov: Prešovská univerzita v Prešove. (http://www.pulib.sk/ elpub2/FF/Olostiak1/index.htm) (Accessed 2020-11-06.)

Giger, Markus \& Giger, Miriam. 2007. Das slowakische Personennamensystem [The system of Slovak personal names]. In Brendler, Andrea \& Brendler, Silvio (eds.), Europäische Personennamensysteme, 688-699. Hamburg: Baar.

Harvalík, Milan. 2004. Synchronní a diachronní aspekty české onymie [Synchronic and diachronic aspects of Czech onymy]. Praha: Academia. Harvalík, Milan. 2006. Komunikační varianty vlastních jmen a jejich místo v onomastické gramatice češtiny [Communicative variants of proper names and their place in the Czech onomastic grammar]. In Rymut, Kazimierz \& Skowronek, Katarzyna \& Czopek-Kopciuch, Barbara \& Malec, Maria (eds.), Munuscula Linguistica. In Honorem Alexandrae Cieślikowa Oblata, 193-200. Kraków: Instytut Języka Polskiego PAN. 
Harvalík, Milan. 2010. Nové tendence v rozvoji současné české onymie [New tendencies in the development of contemporary Czech onymy]. In David, Jaroslav \& Čornejová, Michaela \& Harvalík, Milan (eds.), Mnohotvárnost a specifičnost onomastiky. IV. česká onomastická konference (Ostrava 15.-17. zárí 2009) [Multiplicity and specificity of onomastics. 4th Czech Onomastic Conference (Ostrava 15-17 September 2009)], 179-186. Ostrava - Praha: Filozofická fakulta Ostravské univerzity v Ostravě Ústav pro jazyk český AV ČR, v. v. i.

Harvalík, Milan. 2012. The development of personal names in Czech. In Larsson, Lars-Gunnar \& Nyström, Staffan (eds.), Facts and findings on personal names. Some European examples. Proceedings of an International Symposium in Uppsala, October 20-21, 2011, 59-70. Uppsala: Kungliga Vetenskapssamhället.

Harvalík, Milan. 2013. The dynamism of the development of contemporary Czech onymic systems. In Felecan, Oliviu (ed.), Name and naming. Proceedings of the Second International Conference on Onomastics. Onomastics in Contemporary Public Space, Baia Mare, May 9-11, 4451. Cluj-Napoca: Editura Mega, Editura Argonaut.

Harvalík, Milan. 2016. Přechylování př́imení v češtině z onomastického hlediska [Formation of feminine forms of family names in Czech from the onomastic point of view]. In Molnár Satinská, Lucia \& Valentová, Iveta (eds.), Prechylovanie: áno - nie? [Feminine forms of surnames: yes or no?] (Jazykovedné štúdie. XXXIII.), 23-28. Bratislava: Veda. (http://www.juls.savba.sk/pub_js_33.html) (Accessed 2020-11-06.)

Harvalík, Milan. 2018. Czech first names of foreign origin as witnesses of multicultural contacts in Central Europe. Onomastica Uralica 12, 281-288.

Hlubinková, Zuzana. 1996. Přechýlené podoby ženských př́ijmení ve východomoravských nářečích [The feminine forms of surnames in EastMoravian dialects]. Acta onomastica 37, 54-57.

Knappová, Miloslava. 2008. Naše a cizí prríjmení v současné češtině [Local and foreign surnames in the contemporary Czech language]. Liberec: TAX AZ KORT.

Knappová, Miloslava. 2017. Jak se bude vaše dítě jmenovat? [What will your child's name be?], 6th edition. Praha: Academia.

Kolařík, Josef. 1999. Zvláštnosti flexe příjmení na Luhačovicku [Peculiarities of declension of surnames in the Luhačovice region]. In Klímová, Květoslava \& Kneselová, Helena (eds.), Propria v systému mluvnickém a slovotvorném (Sbornik př̀spěvkì z mezinárodni konference „, Onomastika a škola" konané v Brně ve dnech 10.-11. 2. 1998) [Proper names in the grammatical and word formation systems (Proceedings of the International Conference "Onomastics and School" held in Brno, 10-11 February 1998)], 61-65. Brno: Masarykova univerzita. 
Ladó, János \& Bíró, Ágnes. 2004. Magyar utónévkönyv [Book of Hungarian first names]. Budapest: Vince Kiadó.

Majtán, Milan. 2014. Naše priezviská [Our surnames]. Bratislava: Veda.

Majtán, Milan \& Považaj, Matej. 1998. Vyberte si meno pre svoje diet’a [Choose a name for your child]. Bratislava: Art Area.

Ološtiak, Martin. 2001. O prechyl’ovaní cudzích priezvisk v slovenčine [On word-formation of foreign feminine surnames in Slovak]. Slovenská reč 66(5), 298-308. (https://www.juls.savba.sk/ediela/sr/2001/5/sr2001_5.pdf) (Accessed 2020-11-06.)

Pisárčiková, Mária. 1989. Skracovanie dlhých samohlások v niektorých osobných menách [Shortening long vowels in some personal names]. In Majtán, Milan (ed.), Aktuálne úlohy onomastiky z hladiska jazykovej politiky a jazykovej kultúry. Zborník prispevkov z 2. československej onomastickej konferencie (6.-8. 5. 1987 v Smoleniciach) [Current tasks of onomastics in terms of language policy and language culture. Proceedings of the 2nd Czechoslovak Onomastic Conference (Smolenice 6-7 May 1987)], 147-151. Bratislava: Jazykovedný ústav L'. Štúra SAV.

Pleskalová, Jana. 2007. Das tschechische Personennamensystem [The system of Czech personal names]. In Brendler, Andrea \& Brendler, Silvio (eds.), Europäische Personennamensysteme, 741-748. Hamburg: Baar.

Pleskalová, Jana. 2011. Vývoj vlastních jmen osobnich včeských zemích $v$ letech 1000-2010 [The development of personal proper names in the Czech lands in the years 1000-2010]. Brno: Host.

Pravidlá slovenského pravopisu [Rules of Slovak orthography]. 2013. 4th edition. Bratislava: Veda.

Svoboda, Jan et al. 1983. Osnoven sistem i terminologija na slovenskata onomastika [The basic system and terminology of Slavic onomastics]. Skopje: Makedonska akademija na naukite i umetnostite.

Valentová, Iveta. 2013. Vývin prechyl’ovania ženských priezvisk na slovenskom území [The development of the derivation of feminine surnames from masculine surnames on the Slovak area]. Acta onomastica 54, 272-292.

Valentová, Iveta. 2016. Prechyl’ovanie priezvisk a jeho vývin na Slovensku [The feminine forms of surnames and their development in Slovakia]. In Molnár Satinská, Lucia \& Valentová, Iveta (eds.), Prechylovanie: áno nie? [Feminine forms of surnames: yes or no?], 11-22. (Jazykovedné štúdie, XXXIII.) Bratislava: Veda. (http://www.juls.savba.sk/pub_js_ 33.html) (Accessed 2020-11-06.)

Valentová, Iveta. 2017. Rodné (krstné) mená a kodifikácia [First names and codification]. In Wachtarczyková, Jana (ed.), Aktuálne otázky slovenského jazyka [Current issues of the Slovak language], 163-181. Bratislava: SAP.

Vinczeová, Barbora. 2016. Prechyl'ovanie v preklade ako konflikt medzi zákonom a pôvodným znením s dôrazom na autorky anglického a amerického 
pôvodu [The Slovak suffix -ová in translation as a conflict between the law and the source text with focus on Anglo-American women writers]. In Molnár Satinská, Lucia \& Valentová, Iveta (eds.), Prechyl’ovanie: áno nie? [Feminine forms of surnames: yes or no?], 95-104. Bratislava: Veda. (Jazykovedné štúdie, XXXIII.) (http://www.juls.savba.sk/pub_js_ 33.html) (Accessed 2020-11-06.)

Zákon č. 301/2000 Sb. ze dne 2. srpna 2000 o matrikách, jménu a príjmení a o změně nékterých souvisejících zákonů [Act No. 301/2000 of the Corpus Iuris of 2 August 2000 on registries, names and surnames and on the amendment of certain related laws]. (https://portal.gov.cz/app/zakony/ zakonPar.jsp?idBiblio=49658\&nr=301 2F2000\&rpp=15\#local-content) (Accessed 2020-11-06.)

Zákon č. 312/2013 Sb. ze dne 13. záři 2013, kterým se mění zákon č. 301/2000 Sb., o matrikách, jménu a přijmení a o zmèně některých souvisejicích zákonů, ve znění pozdějšich předpisů, a dalši související zákony [Act No. 312/2013 of the Corpus Iuris of 13 September 2013 amending law No. $301 / 2000$ of the Corpus Iuris on registries, names and surnames and on the amendment of some related laws, as amended, and other related laws]. (https://portal.gov.cz/app/zakony/zakonPar.jsp?idBiblio=80612\& name $=312 \sim 2 F 2013 \&$ rpp $=15 \#$ local-content) (Accessed 2020-11-06.)

Zákon Národnej rady Slovenskej republiky č. 154/1994 Z. z. o matrikách [Act of the National Council of the Slovak Republic No. 154/1994 of the Corpus Iuris on registries]. (https://www.zakonypreludi.sk/zz/1994-154) (Accessed 2020-11-06.)

Zákon Národnej rady Slovenskej republiky č. 300/1993 Z. z. o mene a priezvisku [Act of the National Council of the Slovak Republic No. 300/1993 of the Corpus Iuris on name and surname]. (https://www. zakonypreludi.sk/zz/1993-300) (Accessed 2020-11-06.)

Zákon Národnej rady Slovenskej republiky č. 270/1995 Z. z. o štátnom jazyku Slovenskej republiky [Act of the National Council of the Slovak Republic No. 270/1995 of the Corpus Iuris on the state language of the Slovak Republic]. (https://www.zakonypreludi.sk/zz/1995-270) (Accessed 202011-06.) 